\title{
Assessment of a Protein-Free Medium Performance in Different Cell Culture Vessels using Mouse Hybridomas to Produce Monoclonal Antibodies
}

\section{Rodolfo Valdés ${ }^{1 *}$, Marcos González ${ }^{1}$, Déborah Geada ${ }^{2}$ and Eutimio Fernández ${ }^{3}$}

${ }^{1}$ Monoclonal Antibody Production Department, Center for Genetic Engineering and Biotechnology, Ave. 31/ 158 and 190, PO Box 6162, Havana 10600, Cuba ${ }^{2}$ Tobacco Research Institute, Tumbadero Road km 81/2, San Antonio de los Baños, Havana 3500, Cuba

${ }^{3}$ Nuclear and Energy Research Institute, Ave. Lineu Prestes, 2242, Cidade Universitaria, Butantã, Sao Paulo, 05508-000, Brazil

\begin{abstract}
The main aim of the study was assessing the performance of a Protein Free Medium (PFM) in different cell culture vessels using three mouse hybridomas to produce monoclonal antibodies (mAb) specific for hepatitis B surface antigen, human alpha interferon and a human versica (proteoglycan). In parallel, the influence of the PFM on the hybridoma production kinetic patterns associated to these vessels was also studied. In conclusions, PFM allowed successful hybridoma cultures and mAb production, but showed limitations compared with serum supplemented medium in T-flask, roller-bottle, gas permeable bioreactors and hollow fiber bioreactors. As it was expected, mAb production kinetic pattern was unmodified by the PFM under assessed experimental conditions and the production kinetic pattern analysis is an important tool for indicating the best operation mode for industrial scale $\mathrm{mAb}$ production, but an absolute prediction cannot be totally assumed from these experiments.
\end{abstract}

Keywords: Mammalian cell culture; Monoclonal antibody

\section{Introduction}

The production of monoclonal antibody $(\mathrm{mAb})$ could be achieved by using several culture media and technologies [1-4]. Initially, cell culture media did not guarantee a high cellular density and protein secretion, because their chemical composition was only based on saline isotonic solutions, buffering components and few nutrients [5,6]. These hitches were minimized, supplementing medium with Fetal Bovine Serum (FBS). However, FBS would introduce; contamination risk with bacteria, mycoplasmas, fungi, viruses and prions; and besides availability and cost problems; and regulatory compliances $[7,8]$. The FBS also contains undefined levels of compounds, which can results in lot-to-lot variations and inconsistency to achieve more controlled processes. Therefore, regulatory points to consider of the pharmaceutical industry and cost advice the adoption of serum or protein free cell culture media.

The use of protein free media (PFM) not only represent a better choice in terms of biological safety, but also simplifies purification processes and eliminates bovine immunoglobulin interferences, which is critical for poor $\mathrm{mAb}$ producer hybridomas [9-11]. However, some PFM still remain insufficient to improve mammalian cell culture efficiency, demanding nutrient optimizations [12].

Culture technologies and systems also play an important role in the efficiency of cultures. Commonly, these systems can be divided in stationary (T-flasks), agitated (roller-bottles, spinner-flasks and stirred-tanks) (technology: homogeneous bioreactors) and Hollow Fiber Bioreactors (HFB) (technology: heterogeneous bioreactors) [13], within others. This wide system spectrum offers a diversity of cell densities and mAb concentrations. Therefore, the selection of cell culture medium, technology, vessels and operation mode should be carefully associated with the desired mAb quantity and cell line properties [14].

To predict the best cell culture system and operation mode for large scale production, researchers might use the criterion of the production kinetic patterns. In such sense, three general mAb production kinetic patterns associated with hybridoma cultures were reported years ago $[15,16]$. The Type-I pattern whose shows best $\mathrm{mAb}$ release during the lag phase and on the exponential phase on set. The Type-II pattern is characterized by a high initial $\mathrm{mAb}$ production, which decreases with the cell growth and increases again in the stationary phase and Type-III pattern where $\mathrm{mAb}$ production is stable during cell growth. From this description, it is obvious that the knowledge of these patterns would give valuable information to hypothesize, which culture technology, system and operation mode could preferentially be better for $\mathrm{mAb}$ production. For instance, cells showing Type-I and II patterns might be cultivated in a discontinuous mode, while a continuous mode should be the best choice for Type-III pattern.

Taking into consideration this introduction, this study sought (i) to compare the performance of the PFM TurboDoma ${ }^{\mathrm{TM}} \mathrm{HP}-\mathrm{I}$ in T-flasks and roller-bottles with serum supplemented medium using three mouse hybridomas. (ii) To determine production kinetic patterns of these hybridomas in T-flasks and roller-bottles. (iii) To verify if the TurboDoma ${ }^{\mathrm{TM}} \mathrm{HP}-\mathrm{I}$ could modify production kinetic patterns of these hybridomas in T-flasks and roller-bottles. (iv) To measure the $\mathrm{mAb}$ production of these mouse hybridomas in Gas-Permeable Bioreactors (GPB) and HFB using TurboDoma ${ }^{\mathrm{TM}} \mathrm{HP}-\mathrm{I}$ as cell culture medium.

*Corresponding author: Rodolfo Valdés Véliz, PhD, Monoclonal Antibody Production Department, Center for Genetic Engineering and Biotechnology, Ave 31/ 158 and 190, PO Box 6162, Havana 10600, Cuba; Tel: 537+2504469; Fax: 537+2714764; E-mail: rodolfo.valdes@cigb.edu.cu

Received November 12, 2011; Accepted May 19, 2012; Published May 21, 2012

Citation: Valdés R, González M, Geada D, Fernández E (2012) Assessment of a Protein-Free Medium Performance in Different Cell Culture Vessels using Mouse Hybridomas to Produce Monoclonal Antibodies. Pharmaceut Anal Acta 3:155. doi:10.4172/2153-2435.1000155

Copyright: ( 2012 Valdés R, et al. This is an open-access article distributed unde the terms of the Creative Commons Attribution License, which permits unrestricted use, distribution, and reproduction in any medium, provided the original author and source are credited. 
Citation: Valdés R, González M, Geada D, Fernández E (2012) Assessment of a Protein-Free Medium Performance in Different Cell Culture Vessels using Mouse Hybridomas to Produce Monoclonal Antibodies. Pharmaceut Anal Acta 3:155. doi:10.4172/2153-2435.1000155

Page 2 of 7

\section{Materials and Methods}

\section{Hybridomas and $\mathrm{mAb}$}

The CB.Hep-1 is a mouse hybridoma generated with the "myeloma" SP2/O-Ag14, raised in RPMI 1640/10\% FBS (Gibco, Grand Island, USA), which produces an $\operatorname{IgG}_{2 \mathrm{bk}} \mathrm{mAb}$ directed against the hepatitis B surface antigen [17]. This hybridoma has shown a specific secretion about $10 \mathrm{pg} / \mathrm{cell}$ in T- and spinner-flaks; $2-3 \mathrm{mg} / \mathrm{mL}$ in ascites and 100 $\mu \mathrm{g} / \mathrm{mL}$ in HFB (raising medium).

The CB.Ifn-2,4 is a mouse hybridoma generated with the myeloma X63.Ag8.653, raised in RPMI 1640/10\% FBS (Gibco, Grand Island, USA), which produces an $\operatorname{IgG}_{1 \mathrm{k}} \mathrm{mAb}$ directed against the recombinant human alpha interferon type $2 \mathrm{~b}$ [18]. This hybridoma has shown a specific secretion about $20 \mathrm{pg} /$ cell in T- and spinner-flasks; $4-5 \mathrm{mg} / \mathrm{mL}$ in ascites and 2-3 g/L in HFB (raising medium).

The ETH.13-15 is also a mouse hybridoma generated with the myeloma X63.Ag8.653, raised in IMDM/5\% FBS (PAA, Linz, Austria), which produces an $\operatorname{IgG}_{1 \mathrm{k}} \mathrm{mAb}$ directed against a human versica (proteoglycan).

\section{Cell culture media}

Media used were (SCM) Iscove's Modified Dulbecco's Medium (IMDM) supplemented with $10 \mathrm{~mL} / \mathrm{L}$ of Glutamax ${ }^{\mathrm{TM}} 100 \mathrm{x}$ (Gibco, Grand Island, USA), $50 \mathrm{mg} / \mathrm{L}$ of Gentamicin (Gibco, Grand Island, USA) and 5\% of FBS (PAA, Linz, Austria) with a very low bovine IgG content (served as control medium). The PFM TurboDoma ${ }^{\mathrm{TM}} \mathrm{HP}-\mathrm{I}$ (Cell Culture Technologies, Zürich, Switzerland) supplemented with $10 \mathrm{~mL} / \mathrm{L}$ of Glutamax ${ }^{\mathrm{TM}} 100 x$ (Gibco, Grand Island, USA) and $50 \mathrm{mg} / \mathrm{L}$ of Gentamicin (Gibco, Grand Island, USA).

\section{Cell weaning}

A sequential medium replacement procedure was performed for all hybridomas. Cells were cultivated in SCM and once cell density was approximately $5 \times 10^{5}$ cells $/ \mathrm{mL}$ with more than $95 \%$ of viability were transferred to a mixture of SCM with PFM (25\% of volume). Afterwards, PFM replaces $25 \%$ of SCM every $48 \mathrm{~h}$. The complete SCM replacement was done four days later and then cells were inoculated into different cell culture vessels.

T-flask: Cells at $5 \times 10^{5}$ cells $/ \mathrm{mL}$ were inoculated into $75 \mathrm{~cm}^{2} \mathrm{~T}$-flasks (Techno Plastic Product, Switzerland) in PFM and SCM respectively. After first $24 \mathrm{~h}, 50 \%$ of the T-flask medium volume was daily harvested and centrifuged at $2000 \mathrm{rpm}$ for $10 \mathrm{~min}$. Cells was always maintained at $37^{\circ} \mathrm{C}$ in an atmosphere containing $5-6 \%$ of $\mathrm{CO}_{2}$. Three independent experiments were performed in this vessel.

Roller-bottle: $70 \times 10^{6}$ cells with more than $95 \%$ of viability were inoculated into roller-bottles (Falcon, USA) in PFM and SCM respectively. The roller-bottle velocity was $0.8 \mathrm{rpm}$. Samples were collected every other day and centrifuged at $2000 \mathrm{rpm}, 10 \mathrm{~min}$. Medium replacement was done to keep glucose concentration over $1 \mathrm{~g} / \mathrm{L}$. Cells were also maintained at $37^{\circ} \mathrm{C}$ in an atmosphere containing $5-6 \%$ of $\mathrm{CO}_{2}$. Three independent experiments were performed in this vessel.

GPM: Mini-PERM ${ }^{\mathrm{TM}}$ bioreactors with a molecular weight cutoff $30 \mathrm{kDa}$ membranes (In vitro System and Service, USA) [19] were inoculated with $75 \times 10^{6}$ cells with more than $95 \%$ of viability in $35 \mathrm{~mL}$ of medium. The bioreactor working velocity was $1.5 \mathrm{rpm}$. Harvests were collected every 48 or $72 \mathrm{~h}$ and centrifuged at $2000 \mathrm{rpm}$. Medium was replaced to keep glucose concentration over $1 \mathrm{~g} / \mathrm{L}$ and cells were always maintained at $37^{\circ} \mathrm{C}$ in an atmosphere containing $5-6 \%$ of $\mathrm{CO}_{2}$.

HFB: Cell-Pharm ${ }^{\mathrm{TM}} 100$ systems (Unysin Technologies, Inc, USA) with bioreactors BR130 with a molecular weight cut-off $30 \mathrm{kDa}$ and 1.5 foot $^{2}$ were used [3]. About $250 \times 10^{6}$ cells were inoculated in each bioreactor. In SCM experiments, the FBS was only used in the extracapillary space. After first three days of inoculation, $80 \%$ of the extracapillary volume was manually collected every 48 or $72 \mathrm{~h}$. This harvested volume was applied based on previous experiences to keep high the cell viability. The intracapillary space medium (IMDM without serum supplementation) replacement was also done to keep glucose concentration over $1 \mathrm{~g} / \mathrm{L}$ in the extracapillary space. Experiments with PFM were performed using the same procedure used in the experiments with SCM. Differences were, PFM was used in both bioreactor spaces (intra-and extracapillary spaces) and harvests at the extracapillary space started after seven days post inoculation. The intracapillary space medium flow rate used was always $130 \mathrm{~mL} / \mathrm{min}$.

\section{Cell counting and exponential grow rate (egr) calculation}

Cells were counted using an automatic cell counter (Casy, Germany) following manufacturer recommendations. The EGR was calculated as follow:

where:

$$
E G R=\frac{\operatorname{Ln} X_{2}-\operatorname{Ln} X_{1}}{T_{2}-T_{1}}
$$

$\mathrm{X}_{1}$ and $\mathrm{X}_{2}$ are the number of living cells at the time 1 and 2, respectively.

$\mathrm{T}_{1}$ and $\mathrm{T}_{2}$ are sampling points 1 and 2 , respectively $[15,16]$.

\section{Glucose concentration}

The glucose concentration was determined using an enzymatic kit (catalog number: $345-\mathrm{B}$ ) according to manufacture instructions (SIGMA, St. Louis, USA).

\section{Determination of the mAb Concentration and Specific Production Rate (SPR)}

The mAb concentration was estimated using Protein G-Sepharose micro-affinity chromatography columns (ABICAP (catalog number: 1.01148.0001), Merck, Switzerland) following the protocol recommended by the manufacturer. Details of the validation of this system appear in Valdés et al. [20]. A commercially available immunoglobulin preparation, from SIGMA, St. Louis, USA, was used as standard. The (SPR) was calculated as follow:

where:

$$
S P R=\frac{\left(C_{2}-C_{1}\right)\left(\operatorname{Ln} X_{2}-\operatorname{Ln} X_{1}\right)}{\left(T_{2}-T_{1}\right)\left(X_{2}-X_{1}\right)}
$$

$\mathrm{C}_{1}$ and $\mathrm{C}_{2}$ are $\mathrm{mAb}$ concentrations expressed as $\mathrm{pg} / \mathrm{mL}$ at $\mathrm{T}_{1}$ and $\mathrm{T}_{2}$ respectively.

$\mathrm{X}_{1}$ and $\mathrm{X}_{2}$ are the number of living cells per milliliters at $\mathrm{T}_{1}$ and $\mathrm{T}_{2}$ respectively.

$\mathrm{T}_{1}$ and $\mathrm{T}_{2}$ are times (h) at sampling points 1 and 2, respectively [15, $16]$. 
Citation: Valdés R, González M, Geada D, Fernández E (2012) Assessment of a Protein-Free Medium Performance in Different Cell Culture Vessels using Mouse Hybridomas to Produce Monoclonal Antibodies. Pharmaceut Anal Acta 3:155. doi:10.4172/2153-2435.1000155

Page 3 of 7

\section{Statistical analysis}

Cell culture behavior in T-flask and roller-bottle experiments (maximum cell density, maximum mAb concentration and $\operatorname{IgG}$ production) was evaluated through a t-test to compare the means and the confidence intervals of the two samples. The confidence level used (a) was 0.05 and the Stat Graphics Plus version 5.0 (2000) from Statistical Graphics Corp, USA was used in the statistical analysis.

\section{Results and Discussion}

The replacement of the serum from cell culture media during production of therapeutic proteins offers improved biological safety and can make the regulatory approval smother. The use of non-serum supplemented media is also important to avoid contamination with bovine antibodies, to control experimental variables and to optimize the medium adjusting additives to meet cell individual needs [21]. However, as some non-serum supplemented media can limit cell growth and protein secretion, the culture medium development continues to be an area that offers potentiality to improve protein productivity $[22,23]$.

In this study, the performance of the PFM TurboDoma ${ }^{\mathrm{TM}} \mathrm{HP}-1$, "firstly developed for CHO culture and later optimized for hybridomas", was assessed using three mouse hybridomas in T-flasks and rollerbottles. In addition, hybridoma production kinetic patterns in T-flasks and roller-bottles were determined to verify if this PFM could modify production kinetic patterns of the hybridomas in these vessels. Finally, $\mathrm{mAb}$ production of the hybridomas was also studied in GPB and HFB using TurboDoma ${ }^{\mathrm{TM}} \mathrm{HP}-\mathrm{I}$ as cell culture medium.

Most mouse hybridomas have been successfully weaned to PFM cultivation, which have been helped by sequential weaning applied procedures. In this study, all hybridomas responded also well to the sequential weaned procedure employed. Cell viabilities measured when all cultures were in PFM (to start the vessel assessment) were comparable with those observed in SCM controls (>95\%). However, as a number of changes have been described to take place during adaptation, the growth rate was considered as the most evident change that occurred during adaptation to PFM. And thus, the improvement in growth rate suggested changes in the cells' response to growth in this PFM.

\section{Results of the TurboDoma ${ }^{\mathrm{TM}} \mathrm{HP}-1$ assessment in T-flask}

Due to the low cell density and mAb concentration, T-flask is usually used just to grow cells for the subsequent inoculation of other culture systems. Generally, the maximum cell density started 7 days after the seed and $\mathrm{mAb}$ concentration ranged 10-100 $\mu \mathrm{g} / \mathrm{mL}$ [11]. In this study, culture profiles were characterized by a short lag phase; 1-2 days, which is normal for this system and confirmed the adaptation of cells (Figure 1). The maximum EGR observed were $0.032 / 0.037 / 0.032 / \mathrm{h}$ in SCM and 0.024/0.037/0.068/h in PFM for the CB.Hep-1, CB.Ifn-2.4 and ETH.13-15 hybridomas, respectively. The stationary phase started after 6-7 days achieving an average maximum cell density of $2.1 \times 10^{6}$ cells $/ \mathrm{mL}$ (range $1.9-2.4 \times 10^{6}$ cells $/ \mathrm{mL}$ ) in SCM and $1.4 \times 10^{6}$ cells $/ \mathrm{mL}$ (range 1.4-1.5 $\times 10^{6}$ cells $/ \mathrm{mL}$ ) in PFM. The cell death rate observed was very low in both media (Table 1 ).

The time to achieve the highest $\mathrm{mAb}$ concentration was similar to the time needed to get the maximum cell density (Figure 1). Values of $\mathrm{mAb}$ concentration were $15.5 \mu \mathrm{g} / \mathrm{mL}$ (CB.Hep-1), $21.1 \mu \mathrm{g} / \mathrm{mL}$ (CB.Ifn-
2.4) and $52.6 \mu \mathrm{g} / \mathrm{mL}$ (ETH.13-15) in SCM, while $18.8 \mu \mathrm{g} / \mathrm{mL}, 18.4 \mu \mathrm{g} /$ $\mathrm{mL}$ and $29.1 \mu \mathrm{g} / \mathrm{mL}$ were observed in PFM, respectively. The average maximum $\mathrm{mAb}$ prod

Summarizing, similar to SCM experiments, the time to uction (pg cell $^{-1}$ ) were 21.9 (range 13.3-31.4) in SCM and 16.7 (range 13.2-20.8) in PFM (Table 2). get the maximum cell density ranged 6-7 days in PFM. The maximum cell density showed significant differences between both media $(P=0.0265)$. The EGR was similar for CB.Hep-1 and CB.Ifn-2.4 hybridomas; nevertheless this parameter was almost 2 fold for the hybridoma ETH.13-15 in PFM. Despite of the high cell density achieved in PFM, this medium was stequeometrically limited compared with SCM. The maximum mAb concentration was only marked different between both media in the case of the ETH.13-15 hybridoma. This parameter decreased by $47 \%$ in PFM with respect to SCM, expressing medium limitation for $\mathrm{mAb}$ production in this hybridoma.

\section{Results of the performance of the TurboDoma ${ }^{\mathrm{TM}} \mathrm{HP}-1$ in roller-bottle}

Efficiency of the stationary cell culture is enhanced agitating medium because the poor diffusion process is replaced by agitation and as a consequence cells are supplied with the same nutrients and oxygen more efficiently, increasing $\mathrm{mAb}$ concentration up to $220 \mu \mathrm{g} / \mathrm{mL}$ in the same T-flask culture duration [4].

In this assessment, cell culture profiles showed a lag phase of 2 days in SCM and up to 4 days in PFM (Figure 2). The average maximum EGR
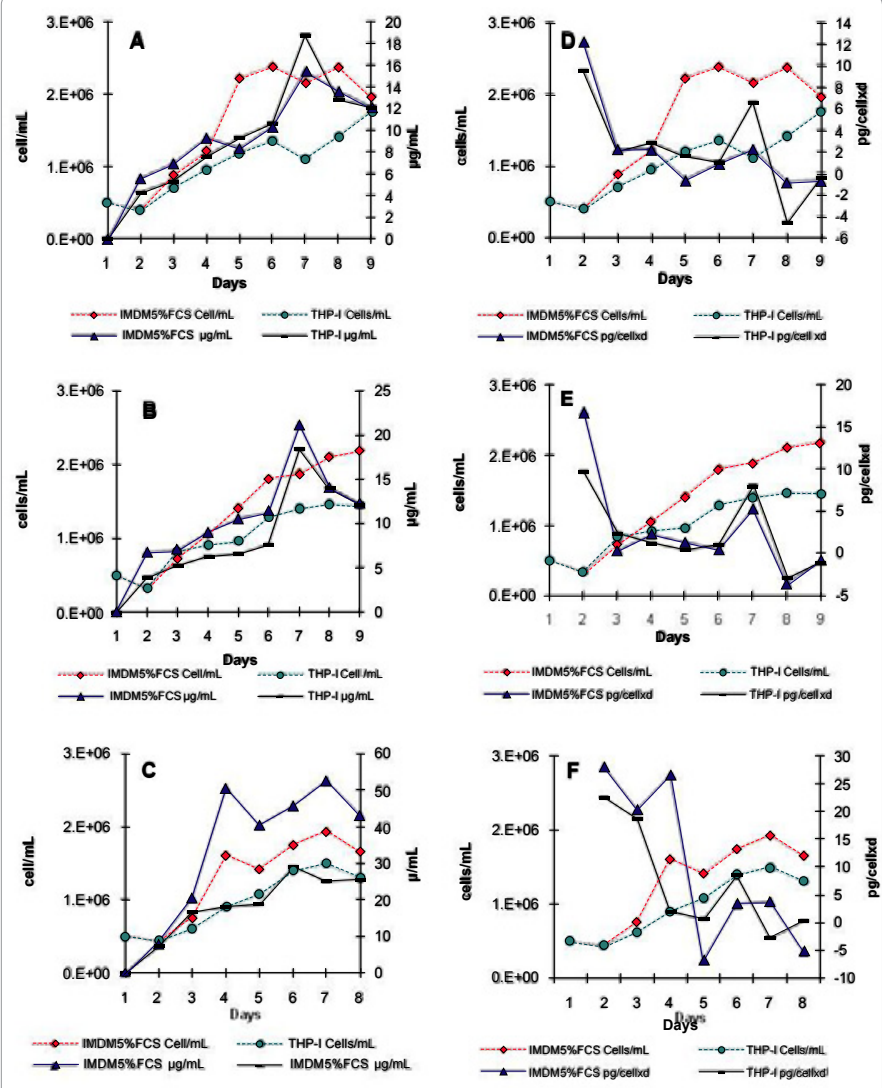

Figure 1: Cell density (cells $/ \mathrm{mL}$ ) and $\mathrm{mAb}$ concentration $(\mu \mathrm{g} / \mathrm{mL}$ ) in T-flasks. CB.Hep-1(A), CB.Ifn-2,4 (B), ETH. 13-15 (C). Production kinetic patterns. CB.Hep-1 (D), CB.Ifn-2,4 (E), ETH.13-15 (F). 
Citation: Valdés R, González M, Geada D, Fernández E (2012) Assessment of a Protein-Free Medium Performance in Different Cell Culture Vessels using Mouse Hybridomas to Produce Monoclonal Antibodies. Pharmaceut Anal Acta 3:155. doi:10.4172/2153-2435.1000155

Page 4 of 7

\begin{tabular}{|c|c|c|c|c|c|c|c|c|c|}
\hline Parameters & $\begin{array}{l}\text { Cell } \\
\text { Lines }\end{array}$ & T-flask (SCM) & T-flask (PFM) & $\begin{array}{l}\text { R-bottle } \\
\text { (SCM) }\end{array}$ & $\begin{array}{l}\text { R-bottle } \\
\text { (PFM) }\end{array}$ & $\begin{array}{l}\text { GPM } \\
\text { (SCM) }\end{array}$ & $\begin{array}{l}\text { GPB } \\
\text { (PFM) }\end{array}$ & $\begin{array}{l}\text { HFB } \\
\text { (SCM) }\end{array}$ & $\begin{array}{l}\text { HFB } \\
\text { (PFM) }\end{array}$ \\
\hline \multirow{3}{*}{$\begin{array}{l}\text { Time of experiment } \\
\text { (days) }\end{array}$} & A & 9 & 9 & 10 & 10 & 20 & 28 & 32 & 37 \\
\hline & B & 9 & 9 & 10 & 10 & 21 & 28 & 32 & 32 \\
\hline & C & 8 & 8 & 10 & 9 & 28 & 28 & 33 & 28 \\
\hline \multirow{3}{*}{$\begin{array}{l}\text { Maximum EGR } \\
\left(h^{-1}\right)\end{array}$} & $A$ & 0.032 & 0.024 & 0.024 & 0.034 & 0.044 & - & - & - \\
\hline & B & 0.037 & 0.037 & 0.037 & 0.058 & 0.032 & 0.026 & - & - \\
\hline & C & 0.032 & 0.068 & 0.035 & 0.026 & 0.032 & 0.043 & - & - \\
\hline \multirow{3}{*}{$\begin{array}{l}\text { Maximum cell density } \\
\left(\text { cells } / \mathrm{mL} \times 10^{6}\right)\end{array}$} & A & $2.38 \pm 0.125$ & $1.37 \pm 0.1000$ & $2.21 \pm 0.085$ & $1.66 \pm 0.127$ & 10.2 & 0.63 & - & - \\
\hline & $B$ & $2.10 \pm 0.066$ & $1.46 \pm 0.075$ & $2.95 \pm 0.135$ & $1.50 \pm 0.127$ & 10.5 & 20.5 & - & - \\
\hline & C & $1.93 \pm 0.185$ & $1.49 \pm 0.091$ & $2.69 \pm 0.271$ & $1.79 \pm 0.096$ & 11.7 & 16.7 & - & - \\
\hline \multirow{3}{*}{$\begin{array}{l}\text { Time to reach the } \\
\text { maximum cell density } \\
\text { (days) }\end{array}$} & A & 6 & 6 & 8 & 9 & 7 & 26 & - & - \\
\hline & $B$ & 7 & 7 & 8 & 9 & 14 & 14 & - & - \\
\hline & C & 7 & 7 & 9 & 7 & 19 & 14 & - & - \\
\hline
\end{tabular}

Table 1: Results of the cell culture behaviour of CB.Hep-1 (A), CB.Ifn-2.4 (B) and ETH.13-15 (C) hybridomas using SCM and PFM in different vessels. The number of experiments were for T-flask $(n=3)$, roller-bottle $(n=3)$, GPM $(n=1$, except for hybridoma CB. Hep-1 in PFN, $(n=2))$ and HFB $(n=1)$. Values of maximum cell density represent the mean and confidence interval $(\alpha=95 \%)$.

ranged $0.024-0.035 / \mathrm{h}$ in SCM and $0.026-0.058 / \mathrm{h}$ in PFM, where the highest EGR were observed in CB.Hep-1 and CB.Ifn-2.4 hybridomas in PFM (Table 1). As a rule the stationary phase started after 8 days at an average maximum cell density of $2.610^{6}$ cells $/ \mathrm{mL}$ (range: 2.2 $2.9 \times 10^{6}$ cells $/ \mathrm{mL}$ ) in $\mathrm{SCM}$ and $1.7 \times 10^{6}$ cells $/ \mathrm{mL}$ (range: $1.5-1.8 \times 10^{6}$ cells $/ \mathrm{mL}$ ) in the PFM were observed (Table 1), expressing significant differences between both media $(P=0.0331)$. In agreement with T-flask experiments, the total cell density in roller-bottles was the same with respect to the viable cell density.

Eight days were needed to achieve the maximum $\mathrm{mAb}$ concentration. Values ranged 20.3-91.9 $\mu \mathrm{g} / \mathrm{mL}$ in SCM and 13.1-48.1 $\mu \mathrm{g} / \mathrm{mL}$ in PFM (Figure 2, Table 2), which also evidenced limitations for $\mathrm{mAb}$ production in PFM (48.9\% decrease). Summarizing, equal to T-flask maximum cell density obtained in SCM was 1.6 fold higher than PFM, confirming that this medium allows a success hybridoma proliferation but with lower efficiency than SCM.

In general, results of maximum cell density, maximum mAb concentration and maximum IgG production determined in PFM experiments using T-flasks and roller-bottles were suitable for hybridoma cell culture, although the comparison of these parameters with SCM demonstrated significant differences for all studied hybridomas.

As general comments a wide range in the antibody production of these three cell lines was observed in T-flasks and roller-bottles. However, this behavior was coincident with those observed in the respective hybridoma isolation medium (see Materials and Methods). Thus, these results were totally dependent on the individual properties of each hybridoma and not on the media used in this study.

\section{Results of the comparison of hybridoma production kinetic patterns observed in t-flasks and roller-bottles}

The production kinetic of the CB.Hep-1 and CB.Ifn-2.4 hybridomas matched with the Type-I pattern because the relative high $\mathrm{mAb}$ production rate was achieved during the lag and at the beginning of exponential phase. While the ETH.13-15 SPR was maintained in parallel with the exponential phase, decreasing at the beginning of the stationary phases, which correspond with a Type-III pattern $[15,16]$. Summarizing, the production kinetic pattern of these hybridomas was unmodified by PFM in these vessels (Figure 1).

The production kinetic pattern is one of the most important parameters to be considered when mAb is going to be produced on industrial scale. Cells showing production kinetic pattern Type- I and II might preferentially be cultivated in a discontinuous mode (repeated batch systems) because growth and SPR are inversely related. Pattern Type-II also implies that cells have to provide a growth phase separated from production phase, which can be achieved by the use of batch, fed batch, repeated batch or continuous system without second stage [16]. If $\mathrm{mAb}$ production is growth associated (Pattern III), continuous mode
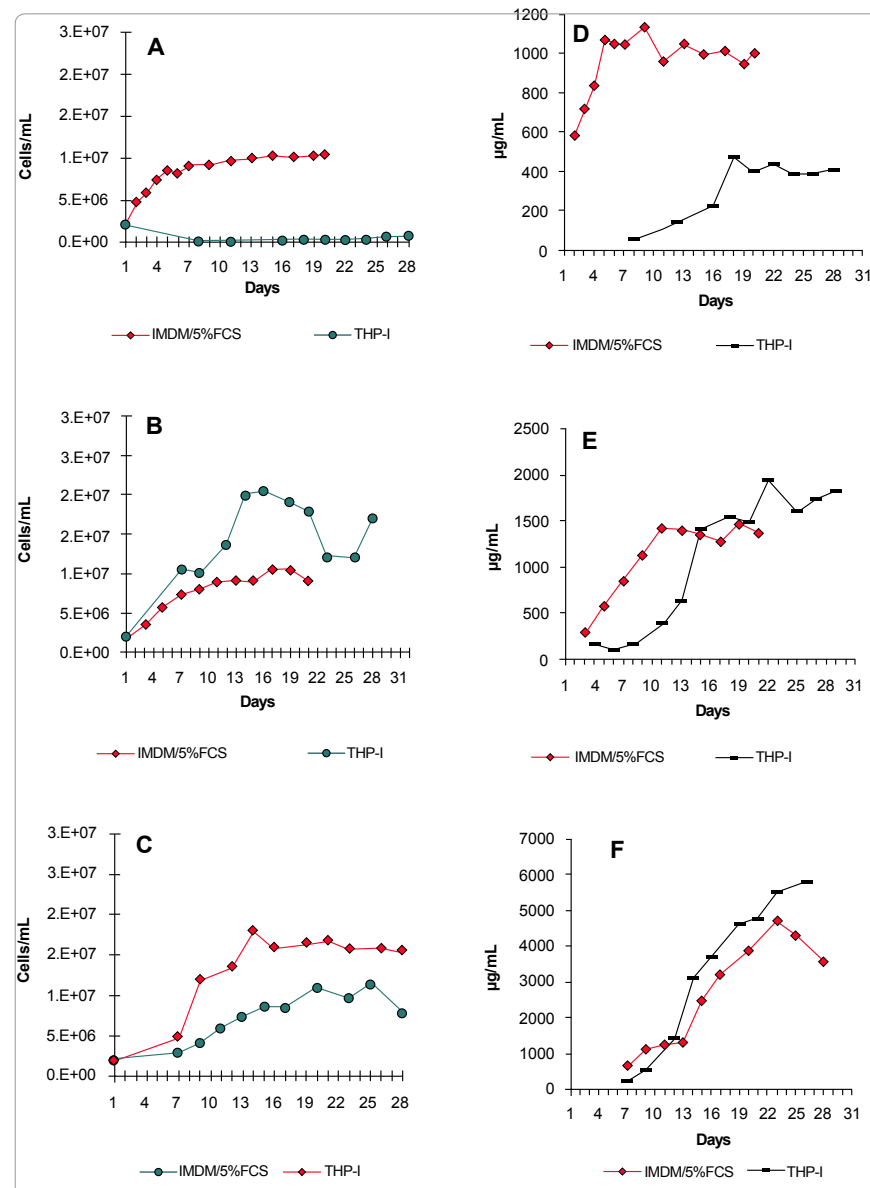

Figure 2: Cell density (cell/mL) and $\mathrm{mAb}$ concentration $(\mu \mathrm{g} / \mathrm{mL})$ in roller-bottles. CB.Hep-I (A), CB.Ifn-2,4 (B), ETH. 13-15 (C). Production kinetic Ppatterns CB.Hep-I (D), CB.Ifn-2,4 (E), ETH.13-15 (F). 
Citation: Valdés R, González M, Geada D, Fernández E (2012) Assessment of a Protein-Free Medium Performance in Different Cell Culture Vessels using Mouse Hybridomas to Produce Monoclonal Antibodies. Pharmaceut Anal Acta 3:155. doi:10.4172/2153-2435.1000155

Page 5 of 7

\begin{tabular}{|c|c|c|c|c|c|c|c|c|c|}
\hline Parameters & $\begin{array}{l}\text { Cell } \\
\text { Lines }\end{array}$ & T-flask (SCM) & T-flask (PFM) & R-bottle (SCM) & R-bottle (PFM) & $\begin{array}{c}\text { GPB } \\
\text { (SCM) }\end{array}$ & $\begin{array}{c}\text { GPB } \\
\text { (PFM) }\end{array}$ & HFB (SCM) & HFB (PFM) \\
\hline \multirow{3}{*}{$\begin{array}{l}\text { Maximum IgG conc. } \\
(\mu \mathrm{g} / \mathrm{mL})\end{array}$} & A & $15.4 \pm 3.571$ & $18.7 \pm 3.762$ & $20.3 \pm 6.027$ & $13.1 \pm 0.753$ & 1134.1 & 475.0 & 1349.0 & 1455.2 \\
\hline & B & $21.1 \pm 3.282$ & $18.4 \pm 5.032$ & $37.7 \pm 4.901$ & $13.7 \pm 0.907$ & 1466.0 & 1944.8 & 1540.0 & 1944.9 \\
\hline & C & $52.5 \pm 8.094$ & $29.1 \pm 5.093$ & $91.8 \pm 9.956$ & $48.1 \pm 7.650$ & 4700.1 & 5785.0 & 4456.3 & 3250.1 \\
\hline \multirow{3}{*}{$\begin{array}{l}\text { Time to reach } \\
\text { maximum IgG conc. } \\
\text { (days) }\end{array}$} & A & 7 & 7 & 8 & 8 & 9 & 18 & 25 & 31 \\
\hline & B & 7 & 7 & 7 & 9 & 11 & 22 & 21 & 22 \\
\hline & C & 9 & 8 & 9 & 8 & 23 & 26 & 21 & 26 \\
\hline \multirow{3}{*}{$\begin{array}{l}\text { Maximum IgG prod. } \\
\text { (pg/cell) }\end{array}$} & A & $13.3 \pm 0.643$ & $16.2 \pm 3.394$ & $29.5 \pm 4.756$ & $16.5 \pm 4.170$ & 110.0 & 754.0 & - & - \\
\hline & $\mathrm{B}$ & $21.2 \pm 2.781$ & $13.2 \pm 3.470$ & $17.7 \pm 5.102$ & $11.8 \pm 2.777$ & 160.8 & 113.5 & - & - \\
\hline & C & $31.4 \pm 6.820$ & $20.8 \pm 6.552$ & $40.6 \pm 5.151$ & $32.9 \pm 4.530$ & 487.6 & 364.2 & - & - \\
\hline \multirow{3}{*}{$\begin{array}{l}\text { Average lgG prod. } \\
\text { (mg/day) }\end{array}$} & A & 0.2 & 0.3 & 1.5 & 1.3 & 9.3 & 1.9 & 2.5 & 2.0 \\
\hline & $B$ & 0.3 & 0.2 & 2.6 & 1.3 & 6.7 & 6.4 & 3.7 & 3.5 \\
\hline & C & 0.7 & 0.8 & 1.4 & 1.8 & 8.5 & 12.1 & 8.8 & 4.1 \\
\hline \multirow{3}{*}{$\begin{array}{l}\text { Total IgG prod. } \\
\text { (mg lgG/run) }\end{array}$} & $A$ & 2.3 & 2.3 & 20.0 & 13.1 & 186.6 & 51.5 & 80.6 & 72.2 \\
\hline & B & 2.6 & 2.1 & 35.1 & 13.4 & 139.7 & 181.9 & 117.8 & 114.9 \\
\hline & C & 7.6 & 4.1 & 77.9 & 53.1 & 239.4 & 341.0 & 291.1 & 155.6 \\
\hline
\end{tabular}

Table 2: Results of the mAb production by CB.Hep-1 (A), CB.Ifn-2.4 (B) and ETH.13-15 (C) hybridomas in SCM and PFM. The number of experiments were: T-flask $(n=3)$, roller-bottle $(n=3)$, GPM ( $n=1$, except for CB.Hep-1 hybridoma in PFN, $(n=2))$ and HFB $(n=1)$. Values of maximum IgG concentration and maximum IgG production represent the mean and confidence interval $(\alpha=95 \%)$.

system should the best choice. Therefore, the best technology, system and operation mode for the CB.Hep-1 and CB.IFn-2,4 hybridomas would be a homogeneous technology, stirred tank and discontinuous mode and a continuous mode for the ETH. 13-15 hybridoma in either both technologies.

To corroborate the prediction based on the production kinetic patters observed in T-flasks and roller-bottles and the influence of the cell culture medium on $\mathrm{mAb}$ production, several experiments were performed in GPB and HFB.

\section{Results of the performance of the TurboDoma ${ }^{\mathrm{TM}} \mathrm{HP}-1$ in the GPB}

The GPB is a reusable minifermentor designed for high cell density hybridoma culture. The main characteristic of GPB is that the production module outer part is a thin gas-permeable membrane to allow efficient oxygen and carbon dioxide exchange. Depending on each cell line, a cell densities between 10 and $35 \times 10^{6}$ cells $\mathrm{mL}^{-1}$ and $\mathrm{mAb}$ concentration of several $\mathrm{mg} \mathrm{mL}^{-1}$ can be obtained in this vessel [19].

Results demonstrated a hybridoma culture profile with a lag phase about 2-7 days in both media, which correspond with those observed with the hybridoma F2154 in different cell culture media [19] (Figure 3). Depending on the medium composition and replacement, hybridoma cell density could reach maximum values in just 5 days, but values up to 27 days to start the harvest have been also observed. The time required to achieve the maximum cell density ranged 7-19 days in SCM and 14-26 days in PFM (Figure 3). The average maximum cell density was $10.8 \times 10^{6} \mathrm{cells} / \mathrm{mL}$ in SCM and $12.6 \times 10^{6}$ cells $/ \mathrm{mL}$ in PFM (Table 1 ). Cell densities $<10 \times 10^{6}$ cells $/ \mathrm{mL}$ were also obtained for hybridomas BLATIII $/ 3\left(5 \times 10^{6}\right.$ cells $\left./ \mathrm{mL}\right)$ and $59-A D 2.2\left(8 \times 10^{6}\right.$ cells $\left./ \mathrm{mL}\right)$ according to Falkenberg [19]. Interestingly, CB.IFn-2.4 and ETH.13-15 hybridomas showed better results when PFM used $\left(20.5 \times 10^{6}\right.$ and 16.7 cells $/ \mathrm{mL}$, respectively). Perhaps, these differences were provoked by the amount of cells attached to the bioreactor membranes when SCM was used, affecting cell counting. Exceptionally, the CB.Hep-1 hybridoma did not grow in this vessel with PFM. The viability of the CB.Hep-1 hybridoma was $>90 \%$ during the time of experiment, but it did not proliferate in PFM reaching a maximum cell density of $0.63 \times 10^{6}$ cells $/ \mathrm{mL}$. We cannot explain this unexpected result yet. An explanation could be related with the inoculum density used in PFM experiment because below certain initial inoculum densities growth can be extremely delayed $[15,24]$ or perhaps some kind of toxicity. Further experiments should be done to corroborate this result.
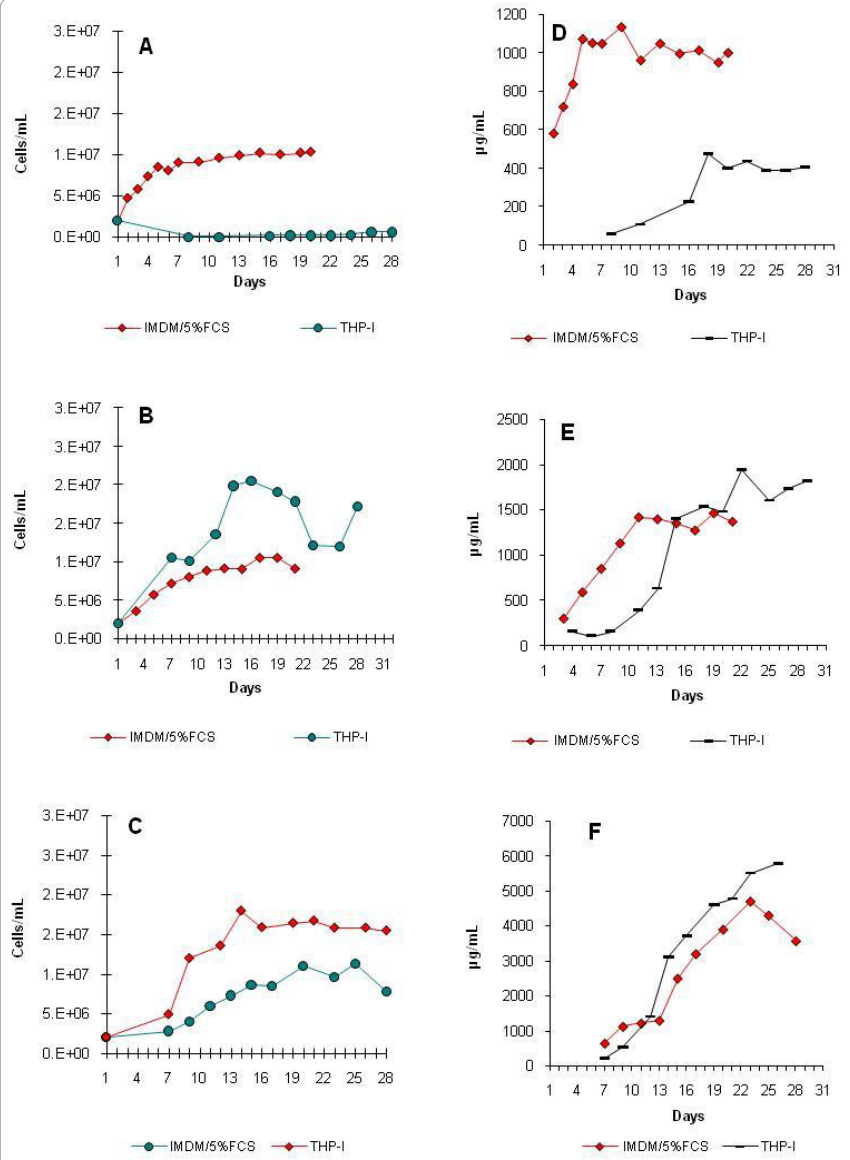

Figure 3: Cell density (cell/mL) in GPB. CB.Hep-I (A), CB.Ifn-2,4 (B), ETH. 1315 (C). mAb concentration ( $\mu \mathrm{g} / \mathrm{mL}$ ) CB.Hep-I (D), CB.Ifn-2,4 (E), ETH.13-15 (F). 
As Figure 3 shows, the time needed to reach the highest $\mathrm{mAb}$ concentration ranged 9-23 days in SCM and 22-26 days in PFM. The average maximum $\mathrm{mAb}$ concentration was $1134.1-4700.1 \mu \mathrm{g} / \mathrm{mL}$ in SCM and 475-5785.0 $\mu \mathrm{g} / \mathrm{mL}$ in PFM. The CB.Ifn-2.4 and ETH.13-15 Hybridomas showed the highest $\mathrm{mAb}$ concentration value in PFM, 40 and $20 \%$ respectively, higher than values observed in SCM (Table 2). Thus, the GPB miniPERM ${ }^{\mathrm{TM}}$ bioreactor, designed for a $\mathrm{mAb}$ production up to $100 \mathrm{mg}$ in 40 days (SCM), would allow the production of these $\mathrm{mAbs}$ as follow 260-340 $\mathrm{mg}$ in 40 days in SCM and 256-484 $\mathrm{mg}$ in 40 days in PFM.

According to the prediction based on the production kinetic patterns observed in T-flasks and roller-bottles, a high $\mathrm{mAb}$ concentration should not be expected with the CB.Hep-1 (SCM) and CB.Ifn-2,4 hybridomas. However, these hybridomas showed a high level of mAb production due to the drastic cell removal protocols at the harvest moments.

\section{Results of the performance of the TurboDoma ${ }^{\mathrm{TM}} \mathrm{HP}-1$ in HFB}

In this study, mAb production agreed well with published data [24] particularly in view of the Type-I production kinetic pattern observed in stationary and agitated cultures for the CB.Hep-1 and CB.Ifn-2.4 hybridomas (Figures 1 and 2). As a practice, the perfusion rate is increased as the cell concentration increase. However, usually the selection of the flow rate is still arbitrary. Therefore, the glucose concentration was used to decide the moment of harvest and medium replacement in this work.

As results, seven days were necessary to show a mAb production increase in SCM meantime up to 17 days in PFM cultures, where the greatest delay was observed for the hybridoma CB.Hep-1 (Figure 4). The $\mathrm{mAb}$ concentration ranged $1349.0-4456.3 \mu \mathrm{g} / \mathrm{mL}$ in SCM and $1455.2-3250.1 \mu \mathrm{g} / \mathrm{mL}$ in PFM (Table 2). A decrease by $20.3 \%$ was observed in this parameter for the hybridoma ETH.13-15 in PFM (Figure 4), suggesting a PFM limitation for $\mathrm{mAb}$ production in this vessel or that operational protocol, perfusion rate, was not sufficiently optimized to permit more productive cell growth and ETH13.15 mAb production. The time needed to reach the highest $\mathrm{mAb}$ concentration also expressed differences between both media (Table 2). The CB.Hep-1 and CB.IFN-2,4 hybridomas manifested up to 7 days delay in PFM (Figure 4). A difference of 2-3 days was only observed for the ETH.13.15 hybridoma.

According to the hybridoma performance prediction made from the production kinetic patterns, hybridomas showing Type-I or II patterns would preferentially be efficiently cultivated in discontinuous mode $[15,16]$. However, results obtained with these Type-I hybridomas demonstrated that the production kinetic pattern analysis is an important tool for $\mathrm{mAb}$ production prediction on large scale, but an absolute prediction cannot be totally assumed from T-flask and roller-bottle results. The CB.Hep-1 and CB.Ifn-2.4 hybridomas produced 80.6 and $117.8 \mathrm{mg} \mathrm{mAb}$ per run (32 days) in SCM; and 52.6 and $114.9 \mathrm{mg}$ mAb per run (32 days) in PFM respectively (Table 2). This is in agreement with values reported by the manufacture for the

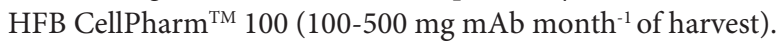

The CB.Hep-1 amount obtained in PFM was $65.2 \%$ of those obtained in SCM, which seems to depend on the cell culture medium and not on the production kinetic pattern because the CB.Ifn-2.4
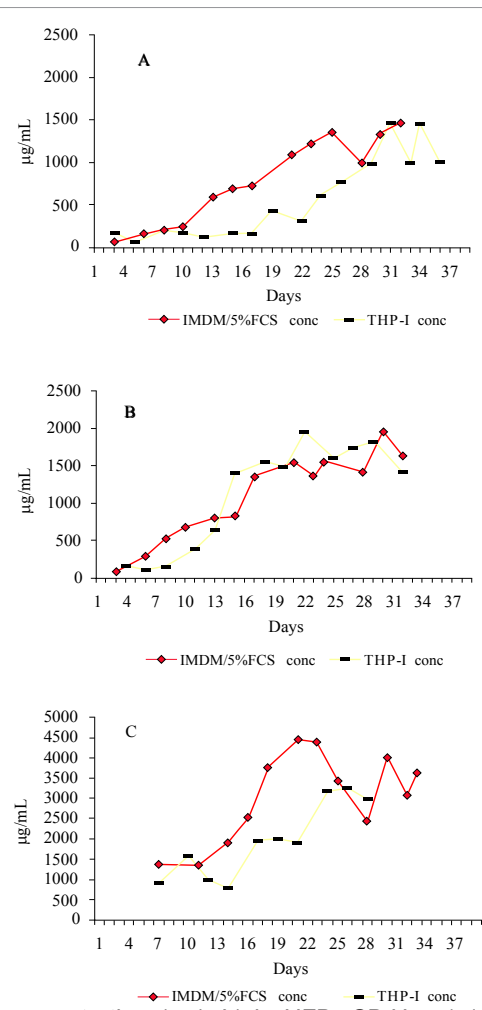

Figure 4: mAb concentration $(\mu \mathrm{g} / \mathrm{mL})$ in HFB. $\overline{C B}^{- \text {THP-I conc }}$ (A), CB.Ifn-2.4 (B), ETH.13-15 (C).

hybridoma did not show differences between both media. Differences in the CB.Hep-1 hybridoma behavior would be explained by the delay to start $\mathrm{mAb}$ production (7 days) in PFM, because cells need to produce firstly their own growth stimulator factors in PFM.

The ETH.13-15 hybridoma (Type-III pattern) produced 205.2 and $155.6 \mathrm{mg} \mathrm{mAb}$ per run (28 days) in SCM and PFM, respectively. It is also within the expected range for this cell culture system, but PFM showed again limitation for $\mathrm{mAb}$ production compared with SCM (Table 2).

An important observation that we would like to share with readers is that the $\mathrm{mAb}$ production plateau phase reached in the HFB for the CB.Hep-1 and CB.IFN-2,4 hybridomas (Type- I production kinetic pattern) was only maintained employed a drastic cell removing protocol during the supernatant harvests.

\section{Conclusions}

The PFM allows success in hybridoma cultures and $\mathrm{mAb}$ production, but showed some limitations for cell growth and $\mathrm{mAb}$ production compared with IMDM supplemented with FBS. Therefore, as with many other PFM, nutrient optimization of the PFM used in this study is needed to allow the growth and mAb production of theses hybridomas like IMDM supplemented with FBS. As it was suspected, the PFM was unable to modify the mAb production kinetic pattern of the hybridomas assessed in this study. The production kinetic pattern analysis is an important parameter to be considered for indicating the operation mode for $\mathrm{mAb}$ that have to be produced on industrial scale, but an absolute prediction cannot be totally assumed from T-flask and roller-bottle results. 
Citation: Valdés R, González M, Geada D, Fernández E (2012) Assessment of a Protein-Free Medium Performance in Different Cell Culture Vessels using Mouse Hybridomas to Produce Monoclonal Antibodies. Pharmaceut Anal Acta 3:155. doi:10.4172/2153-2435.1000155

\section{Acknowledgments}

Authors gratefully acknowledge Dr. René Fischer from Federal Institute of Technology of Zürich, Switzerland for the technical assistance, financial support of the study, and also for provided the hybridoma ETH.13-15.

\section{References}

1. Yokoyama WM (2008) Production of monoclonal antibody supernatant and ascites fluid. Curr Protoc Mol Biol Chapter 11: Unit 11.10.

2. Susan DJ, Castillo FJ, Levine HL (2007) Advances in the development of therapeutic monoclonal antibodies. BioPharm International; 96-114.

3. Chiarella P, Fazio VM (2008) Mouse monoclonal antibodies in biological research: strategies for high-throughput production. Biotechnol lett 30: 13031310.

4. Véliz RV (2002) Alternative Techniques to Obtain Monoclonal Antibodies at a Small Scale: Current State and Future Goals. Biotecnología Aplicada 19: 119-131.

5. Jayme D, Watanabe T, Shimada T (1997) Basal medium development for serum-free culture: a historical perspective. Cytotechnology 23: 95-101.

6. Jayme DW, Smith SR (2000) Media formulation options and manufacturing process controls to safeguard against introduction of animal origin contaminants in animal cell culture. Cytotechnology 33: 27-36.

7. Nairn C, Lovatt A, Galbraith DN (2003) Detection of infectious bovine polyomavirus. Biologicals 31: 303-306.

8. Schiff LJ (2005) Review: production, characterization, and testing of banked mammalian cell substrates used to produce biological products. In Vitro Cell Dev Biol Anim 41: 65-70.

9. Parampalli A, Eskridge K, Smith L, Meagher MM, Mowry MC, et al. (2007) Developement of serum-free media in CHO-DG44 cells using a central composite statistical design. Cytotechnology 54: 57-68.

10. Even MS, Sandusky CB, Barnard ND (2006) Serum-free hybridoma culture: ethical, scientific and safety considerations. Trends Biotechnol 24: 105-108.

11. Brunner D, Frank J, Appl H, Schöffl H, Pfaller W, et al. (2010) Serum-free Cel Culture: The Serum-free Media Interactive online Database. ALTEX 27: 53-62.

12. Maizirwan M, Maizura MS, Yumi Zuhanis HH, Mohamad Ramalan MS (2008)
Monoclonal antibody production: media optimization for enhancement the cell viability of hybridoma cell. Asian Journal of Scientific Research 1: 525-531.

13. Chu L, Robinson, DK (2001) Industrial choices for protein production by largescale cell culture. Curr Opin Biotechnol 12: 180-187.

14. Hacker DL, Nallet S, Wurm FM (2008) Recombinant protein production yields from mammalian cells: past,present, and future. BioPharm International Supplement; 6-15.

15. Merten OW (1988) Batch production and growth kinetics of hybridomas Cytotechnology 1: 113-121.

16. Merten OW, Reiter S, Himmler G, Scheirer W, Katinger H (1985) Production kinetics of monoclonal antibodies. Dev Biol Stand 60: 219-227.

17. Fontirrochi $G$, Dueñas $M$, Fernández de Cossio ME, Fuentes $P$, Pérez $M$, e al. (1993) A mouse hybridoma cell line secreting IgG and IgM antibodies with specificity for the hepatitis B virus surface antigen. Biotecnología Aplicada 10 24-30.

18. Cruz S, Duarte C, Ferrá E, Fontirrochi G, Vázquez J, et al. (1990) Quantification of human alpha $2 b$ interferon using monoclonal antibodies. Biotecnología Aplicada 7: 132-141.

19. Falkenberg FW (1998) Production of monoclonal antibodies in the miniPERM bioreactor: comparison with other hybridoma culture methods. Res Immuno 149: $560-570$.

20. Valdés R, Leyva A, Geada D, Fernández EG, Padilla S, et al. (2008) Quantification of Monoclonal Antibodies from Bioreactor Supernatants Using Protein-G Sepharose Chromatography. Chromatographia 67: 109-112.

21. Seaver S, Rudolph JL, Ducibella T, Miller L (1984) Hybridoma cell metabolism and antibody secretion in culture. Presented at Biotech' 84, USA.

22. Zhang J, Robinson D (2005) Development of Animal-free, Protein-Free and Chemically-Defined Media for NSO Cell Culture. Cytotechnology 48: 59-74.

23. Peppers S, Allison D, Johnson T, Damon T, Caple M (2001) Performanceoptimized hybridoma medium: replacing serum and other animal-derived components. LifeScience 2: 6-10.

24. Dewar V, Voet $P$, Denamur F, Smal J (2005) Industrial implementation of in vitro production of monoclonal antibodies. ILAR J 46: 307-313. 